\title{
10.2478/genst-2018-0001
}

\section{POWERFUL EMBLEMS OF PROTEST: FLOWER LANGUAGE AND FLOWER IMAGERY IN THE WRITINGS OF MARGARET FULLER}

\author{
ELISABETTA MARINO \\ University of Rome "Tor Vergata" \\ Via Orazio Raimondo, 18, 00173 Rome, Italy \\ emarino@hurricane.it
}

\begin{abstract}
This essay aims at exploring the controversial and thought-provoking use of flower language and flower imagery in Margaret Fuller's so-called flower pieces. In a rather unconventional way, this language for women is turned by the writer into a powerful instrument of protest, capable of upsetting stereotypes and common beliefs on women.
\end{abstract}

Keywords: flower language, flower pieces, gender expectations, Margaret Fuller, self-empowerment

\section{Introduction: Women as Flowers}

By focusing primarily on the so-called flower pieces composed by Margaret Fuller throughout her artistic career, this essay sets out to explore her provocative and unconventional use of flower language and flower imagery, employed as powerful instruments to challenge assumptions concerning gender prerogatives and expectations, while encouraging women's self-determination, autonomy, and empowerment. Before delving into the analysis of her texts (both poems and prose sketches), a brief introduction to the significance of flowers in the culture of nineteenth century America will be necessary, as they acted as models of female virtue but also operated as vehicles for coded messages, as a controversial replacement for verbal communication at a time when women were seldom encouraged to present their views in public and manifest their needs.

In her seminal essay on the cult of true womanhood, Barbara Welter (1966:152) identified "piety, purity, submissiveness and domesticity" as the fundamental pillars of a proper lady's personality, besides emphasizing the inextricable connection between the domesticated space of the garden and the true woman, who was supposed to share a natural affinity with flowers (given their graceful, innocent, and delicate appearance), thus having a deeper insight into their essence (Welter 1966:165). Indeed, especially in the first half of the nineteenth century, the garden turned into "the chosen and consecrated terrain of the feminine sensibility" (Douglas 1998:369), borrowing the words of Ann Douglas. Since women were expected to nurture flower-like qualities, gift annuals and newly established ladies' periodicals (hardly ever edited by men) frequently displayed flower names in their titles (The Violet, The Ladies' 
Wreath, and The Lily of the Valley, just to list a few) for sheer marketing reasons, in order to capture the attention of those who were seeking for guidance and instruction.

\section{The Language of Flowers and Floral Lexicons}

Floral lexicons and beautifully illustrated flower dictionaries penned by women writers also multiplied. As Dorri Beam (2010:38) has observed, these volumes, eagerly consumed by an increasingly large female readership, were all rather similar: drawing details from the Bible, classical mythology, and folklore, they disclosed the symbolic meaning of each flower, the sentiment associated with it, while featuring lines from famous poems aimed at further elucidating its secret significance. A glossary of botanical terms was also included in most volumes, together with information concerning the class, the order, the native country of every plant. The meticulous attention to scientific accuracy paid by the majority of compilers should not be mistaken for a daring incursion into realms positively forbidden to ladies: in its connection with objects of beauty and with the ideas of precision, neatness, and organization, botany was then regarded as the science for women par excellance; as Caroline JacksonHoulston (2006:88) has highlighted, it confined them "to the home and garden, both physically and mentally". Predictably, the general tone of flower dictionaries was moralizing and didactic; moreover, their authors exhibited such a modest and self-effacing attitude that their violation of the doctrine of the separate spheres, performed through the act of publishing their literary endeavours, passed almost unnoticed, without posing a threat to the cultivation of truly womanly virtues. For instance, in the Preface to her best-selling Flora's Dictionary (1829), Elizabeth Washington Writ (1837:3), described her text as a "petit jeu", "a trifle", a "little divertissement" (Washington Writ 1837:4), and a "bagatelle" (Washington Writ 1837:4). Likewise, Sarah Hale (1835:v), whose popular Flora's Interpreter (1832) remained in print for four decades, humbly compared her creative process - the making (not the writing, as she herself pointed out) of her "little work" - to preparing a meal, "the ingredients [...] collected from many places". The wordless language of flowers was not just the most suitable form of expression for meek and silent ladies, the ornaments of every gentleman's house. Disturbingly enough, it was introduced in Flora's Dictionary as a manipulative tool, as a language for women that had to be mastered by men in order to conquer their longed-for preys: in the words of Elizabeth Washington Writ (1837:4), "there are few little presents more pleasing to a Lady, than a bouquet of flowers; and, if the donor be disposed to give them greater significance, it will be easy, with this manual before him, to make his selection in such a way as to stamp intelligence and expression on a simple posy".

Despite what has been argued so far, the historical origins of the language of flowers compellingly reveal its socially destabilizing potential, besides uncovering its deep connection with sensuality and eroticism, an aspect which was deliberately overlooked in the American context by virtually every dictionary compiler. As Corinne Kopcik Rhyner has underlined (2012:2), the Austrian Orientalist Joseph Hammer-Purgstall published the first floral lexicon in Europe in 1809, after studying the Turkish tradition of Sélam, a secret code of communication 
according to which the exchange of specific objects (especially flowers) allowed harem inmates to share their feelings with their male or even female lovers, both inside and outside the seraglio. This essential and subtly subversive side of flower language possibly exercised a potent fascination over Margaret Fuller, who was also certainly aware of the recent botanical discovery of the floral reproductive system and its functions and processes, which undoubtedly questioned the widespread perception of flowers as ethereal and flawless creatures of God.

\section{Margaret Fuller's Enduring Interest in Flowers}

Margaret Fuller's lifelong interest in flower language and flower imagery is embedded in both her private papers (letters and journal entries) and major works. As Thomas Wentworth Higginson (1884:19) noticed in his Life of Margaret Fuller Ossoli, the writer inherited a passion for flowers from her mother, who took pleasure in her perfectly tended garden, and divided her life "between her children and her flowers", withdrawn into what the biographer termed "a sort of double domesticity". In her "Introductory Chapter to an Autobiographical Romance" (a sketch of her youth, composed when Fuller was nearly thirty), she portrayed her mother as "one of those fair and flower-like natures, which sometimes spring up even beside the most dusty highways of life" (Fuller 1852:5), a rather provocative reformulation of a clichéd depiction, since it forcefully removes the maternal figure from the private realm of the household (peopled by immaculate and disembodied females), and casts her into an all-too-human, imperfect, and public dimension. A few pages later she fondly described her little garden, "full of choice flowers and fruit trees", where, during her childhood, she "felt at home", surrounded by the "silvery wreaths of [her] protective vine" (Fuller 1852:21). Interestingly enough, the author's feelings of delight and security never stemmed from her strictly domestic environment (the family mansion). Furthermore, thus blurring the boundaries between traditionally gendered spaces, she even associated her indoor activities with her overbearing father, who had unnaturally educated her beyond her years, as she would complain later on in life, blaming her strict upbringing for the health problems she often experienced. The writer's challenging use of flower images can also be detected in her Summer on the Lakes (1844), a sort of travel narrative interspersed with digressions, where the peculiar personality of Mariana (one of Fuller's fictional personae, an open and enthusiastic woman) is not assimilated to a timid lily or a sweet rose, but to "a fire of cinnamon" (1861:94), whose scent is too strong to endure.

\section{Margaret Fuller's Flower Pieces}

Leaving aside the cursory (though copious) references to flowers in most of her output, Margaret Fuller wrote quite a number of flower pieces which, apparently, she held in high esteem. As she wrote to her friend William Henry Channing,

You often tell me what to do when you are gone; if you survive me, will you not collect my little flower pieces, even the insignificant ones? I feel as if from mother I had received a connection with the flowers; she has the love, I the interpretation. My writing about them are no fancies, but whispers from themselves. (Wentworth Higginson 1884:97-98) 
As the last sentence clearly indicates, by serving as a mere spokesperson, she wished to give back a voice to the silenced ones (not just to flowers but also to flower-like women), who could eventually manage to tell their own, probably different version of the story, without being spoken for. Accordingly, very few of Fuller's flower poems faithfully adhere to the conventions of flower dictionaries; "To Sarah", written in 1844 and dedicated to Sarah Clarke (one of her travelling companions on her tour around the lakes), provides a fair example. Aiming at praising her earnestness and simplicity, the writer likened her to "a sweet fern" (Kopcick Rhyner 2012:25), whose meaning in the language of flowers is sincerity and youthful innocence. Other times, she intentionally reversed the traditional sentiment reported in floral lexicons; in "The Passion-Flower", the symbol of religious fervour and holy love (according to Sarah Hale [1835:143] and Elizabeth Washington Writ [1837:91], respectively) is transformed into the emblem of a deceitful love, doomed to fade (notwithstanding the efforts and the abundant tears of the lady involved in the liaison), due to its intrinsic, ephemeral nature (Fuller 1918:1053). The asymmetrical relationship between men and women is further explored in a witty poem published in The Dial in July 1840, ironically entitled "A Dialogue", featuring an improbable couple - namely a dahlia and the Sun - characterized by lack of real communication and mutual understanding. In Washington Writ's dictionary [1837:86] the dahlia stands for everlasting love ("forever thine"), while in Hale's lexicon [1835:54] it expresses elegance and dignity. Humorously enough, by using a language charged with overtly sexual innuendoes, Fuller's [1841:134] inelegant and undignified dahlia shamelessly invites the Sun to "descend" on her, since she is "all crimson for the bridal hour" (an evident allusion to her desire for defloration). Nonetheless, thoroughly indifferent to her urges and needs, the Sun refuses to linger: his job in the world outside the domestic hearth is more important ("I love thee, lustrous flower, but give to love no hour"). Fuller's recommended remedy for this form of deeply-ingrained cultural injustice (the preeminence of men over women) is offered in another poem (probably written at the end of 1839) that she sent to Caroline Sturgis, one of her young protégées: "Lines Accompanying a Bouquet of Wild Columbine, which Bloomed Late in the Season". Fuller's columbine (a sorrowful symbol of desertion in Sarah Hale's volume [1835:254]) develops into a stately icon of independence and resistance to the values of a patriarchal society that pushed women to enter marriage at an early age, thus abandoning any other hope of self-realization. Hence, her wild flower (and the renewed flower-like woman the author fostered) is depicted as "self-nurtured, self-sustained, self-approved" [Fuller 1869:375], capable of thriving in every ground and condition (not necessarily in the comfortable and domesticated - albeit limited space of the garden). In the final part of her poem, therefore, the author prompts her addressee to learn not just the traditional womanly virtues associated with lilies, roses and heliotropes. As she gravely states,

Learn from the columbine to live alone,

To deck whatever spot the Fates provide

With graces worthy of the garden's pride, 
The message of "Lines Accompanying a Bouquet of Wild Columbine" profoundly informs the two flower sketches Margaret Fuller published in two separate issues of The Dial in the same period: "The Magnolia of Lake Pontchartrain" (1841) and "Yuca Filamentosa" (1842). As Charles Capper (2007:44) has elucidated, the two "densely esoteric and relentlessly allegorical" stories, "have usually struck scholars as impossible to decipher, much less digest". Inspired by the oral narratives of an eccentric family friend (Dr. William Eustis, who had told Margaret about his mystical encounters with a Magnolia and two yuccas), the flower pieces were also influenced by the German Romantics, and by Neoplatonic writers dealing with the subject of metempsychosis (Wentworth Higginson 1884:96). In Corinne Kopcik Rhyner's opinion (2012:75), "The Magnolia of Lake Pontchartrain" also reflected "the emotional and imaginative turmoil" Fuller experienced after the wedding of a very close friends, Anna Barker, in October 1840. The author was probably afraid that, trapped in a burdensome marital life, Anna would regretfully abandon her intellectual pursuits. "The Magnolia of Lake Pontchartrain" tells the story of a traveller who, captivated by an unusual yet alluring scent, decides to divert his route to find its source. In the wilderness, near a lake, he finally discovers the origin of the appealing smell: a giant magnolia in full bloom, whose female spirit he had already met, earlier on in his life, when she breathed in the shape of an orange tree, before her transmigration. The story develops as a dialogue (a real dialogue, this time), even though the magnolia speaks more extensively than her interlocutor, thus signifying Fuller's intention to place a stronger emphasis on the language of the flower rather than on flower language, often appropriated and manipulated (as already noticed) by men. The magnolia explains the reasons that had caused her to abandon her previous arboreal body by picturing her life as an orange tree as the mirror image of the selfless and dutiful existence of a true woman. She enjoyed no freedom in her pretty pot; besides, her wordless language identified exclusively with the bounty of gifts she had to bestow upon those relying on her:

I was never silent. I was never alone. I had a voice for every season for day and night. On me the merchant counted, the bride looked to me for her garland, the nobleman for the chief ornament of his princely hall, and the poor man for his wealth. [...] I had no mine or thine, I belonged to all, I could never rest, I was never at one. (Fuller 1841:302)

Tired of being so despoiled, she hoped for a change, which arrived when a sudden cold breeze turned "the pride of the garden" into a "black, stiff, and powerless" (Fuller 1841:303) creature, immediately replaced by her owner with a fresh and vigorous plant, even though she was still alive and might have been restored to health. As Margaret Fuller seems to suggest, in any patriarchal context, commodified women, devoid of individuality, are actually interchangeable; what is more, their value lies solely in their fecundity and ornamental quality. All the same, the soul of the orange tree is granted the possibility of a new earthly life by the Guardian of the Flowers (one of the numerous Mother Goddesses that, in Fuller's revolutionary vision of an 
afterlife, take collectively the place of God the Father). She becomes a solitary magnolia, a magnificent and imposing tree (not a delicate flower) described as "the Queen of the South", as a "stately tower of verdure, each cup, an imperial vestal" (Fuller 1841:300). The reference to Vestals (sworn to celibacy for thirty years) is not fortuitous: it seemingly aims at disentangling the concept of female worth and beauty from the generative power of women (be it said incidentally, in Sarah Hale's dictionary [1835:139] the orange tree flower means exactly “woman's worth"). The fragrant magnolia, in fact, freely exhibits her lush, attractive blossoms, employing her sensuality to attract passers-by (including the male traveller); yet, the tree produces no fruit, nor can the virginal white flowers be plucked and arranged in a vase, since they defiantly "refus[e] to retain their dazzling hue, but droo[p] and gr[o]w sallow, like princesses captive in the prison of a barbarous foe" (Fuller 1841:300). In "The Magnolia of Lake Pontchartrain", as Dorri Beam (2010:46) has pointed out, "the language of flowers facilitates a love affair, but it is an affair with the self".

"Yuca Filamentosa" represents Margaret Fuller's new entry to a reformed flower dictionary, featuring a language belonging to women (women's language), not just a language for women: in fact, this strong, resistant, and evergreen flowering plant, able to prosper in any soil without being tended or cultivated, is not even mentioned in any floral lexicon. Written from the point of view of a female narrator, the prose sketch tells the story of the beautiful first blooming of two yuccas during a full-moon night, after several years of flowerless life. At the beginning of the narrative, the yuccas are associated with Diana, the moon's form on Earth, another maiden Goddess who, nevertheless, protected women during childbirth. What Margaret Fuller conjures up in "Yuca Filamentosa" is a gentle, all-female community where women support and shelter one another, and are allowed to develop their creative potential at their own pace. It is not by chance that the yucca flowers of the first plant to bud seem "to be waiting for the other" (Fuller 1842:287) before blooming; likewise, it is not a coincidence that both shrubs wait for the moon to be at its fullest, before sharing their majestic beauty with the narrator, captivated by the filaments of what seems to be "a robe [...] of silver" (Fuller 1842:287) for the "Queen of night" (Fuller 1842:288). Unsurprisingly, the flowers' contact with the masculine world is traumatizing: the arrogant impetuosity of the Sun (that, it should be remembered, had shunned the dahlia in Fuller's 1840 poem) makes the blossoms wither. Still, at night they easily resume their usual splendour. The Sun is not the only male character in the story; the narrator wishes to share her epiphanic experience with her partner, Alcmeon, initially introduced as grossly insensitive to femininity, "one who could travel amid the magnificent displays of the tropical climates, [and] not even look at a flower" (Fuller 1842:287). As the writer remarks, however, a balance between the sexes is eventually restored through the contemplation of nature: Alcmeon's "obtuseness" is "conquered" by "the piercing sweetness of this flower's look in its nuptial hour" (Fuller 1842:288). The adjective "nuptial" is ironically used by Fuller, since no male seems to be involved in the generative process, "the flower brood[ing] on her own heart" (Fuller 1842:288). According to Corinne Kopcik Rhymer (2012:55), "Yuca Filamentosa" is also an appeal to women "to delay reproduction in order to establish 
themselves", to bloom "late in the season", like the columbine of Fuller's poem, or to nurture loneliness and self-reliance, like the magnolia of Lake Pontchartrain.

\section{Conclusion}

To conclude, as this essay tried to demonstrate, Margaret Fuller's early feminist flower pieces deserve closer scholarly attention. Through them, the writer compellingly succeeded in subverting the meaning usually attached to flower language and flower imagery, transformed by her pen into challenging instruments to promote women's enhancement and independence.

\section{References:}

Beam, D. 2010. Style, Gender, and Fantasy in Nineteenth Century American Women's Writing. Cambridge: Cambridge University Press.

Capper, C. 2007. Margaret Fuller: An American Romantic Life, Vol. II, The Public Years. Oxford: Oxford University Press.

Douglas, A. 1998. The Feminization of American Culture. New York: Farrar, Straus and Giroux.

Fuller, M. 1841 (1840). “A Dialogue” in The Dial, vol. I. Boston: Weeks, Jordan and Company, p.134.

---. 1841. "The Magnolia of Lake Ponchartrain” in The Dial, vol. I. Boston: Weeks, Jordan and Company, pp.299305 .

---. 1842. "Yuca Filamentosa" in The Dial, vol. II. Boston: E. Peabody, pp.286-88.

--- 1852. "Introductory Chapter to an Autobiographical Romance" in Memoirs of Margaret Fuller Ossoli, vol. I.

W.H. Channing, J.F. Clarke, and R.W. Emerson (Eds.). London: Richard Bentley, pp.3-70.

--- 1861 (1843). Summer on the Lakes with Autobiography. London: Ward and Lock.

---. 1869. "Lines Accompanying a Bouquet of Wild Columbine Which Bloomed Late in the Season" in Life Without and Life Within or Reviews, Narratives, Essays, and Poems by Margaret Fuller Ossoli. A.B. Fuller (Ed.). New York: The Tribune Association, pp.375-76.

---. 1918. "The Passion Flower" in The Home Book of Verse, American, and English, 1580-1918. B.E. Stevenson (Ed.). New York: Henry Holt and Company, p.1053.

Hale, S. 1835 (1832). Flora's Interpreter. Boston: Marsh, Capen and Lyon.

Jackson-Houlston, C. 2006. “'Queen Lilies?’ The Interpenetration of Scientific, Religious and Gender Discourses in Victorian Representations of Plants." Journal of Victorian Culture 11(1):84-110.

Kopcik Rhyner, C. 2012. Flowers of Rhetoric: The Evolving Use of the Language of Flowers in Margaret Fuller's Dial Sketches and Poetry, Elizabeth Stoddard The Morgesons, Edith Wharton's Summer, Mary Austin's Santa Lucia and Cactus Thorn, and Susan Glaspell's The Verge. PhD Dissertation, Georgia State University.

Washington Writ, E. 1837 (1829). Flora's Dictionary. Baltimore: Fielding Lucas.

Welter, B. 1966. "The Cult of True Womanhood: 1820-1860.” American Quarterly 18(2):151-174.

Wentworth Higginson, T. 1884. Margaret Fuller Ossoli. Boston and New York: Houghton Mifflin Company. 